\title{
Advokasi Hukum Penyelesaian Konflik Tanah Di Desa Palihan Akibat Pembangunan Bandara
}

\author{
Martinus Sardi, King Faisal Sulaiman, Yordan Gunawan \\ Program Studi Hukum, Fakultas Hukum, Universitas Muhammadiyah Yogyakarta. \\ Email: msardi123@gmail.com \\ DOI: $10.18196 /$ ppm.32.189
}

\begin{abstract}
Abstrak
Program pengabdian ini berjudul "Penguatan Advokasi Hukum Penyelesaian Konflik Tanah di Desa Glagah dan Desa Palihan sebagai Masyarakat Terdampak Pembangunan Bandara NYIA-Kulonprogo, Daerah Istimewa Yogyakarta”. Program ini bertolak dari fakta empiris bahwa meskipun Bandara NYIA telah mulai beroperasi pada April 2018, tetapi penyelesaian hukum terkait konflik tanah bagi warga terdampak belum terselesaikan secara baik. Tujuan dari program ini adalah meningkatkan pengetahuan, kapasitas, dan kemampuan mengorganisasikan diri dalam membangun posisi tawar, memperjuangkan, dan menuntut secara hukum hak-hak yang terlanggar akibat proses pelepasan tanah/ganti rugi untuk pembangunan Bandara NYIA oleh warga terdampak, khususnya di Desa Glagah dan Desa Palihan-Kecamatan Temon. Warga terdampak di kedua Desa ini masih minim sosialisasi dan pengetahuan terkait (a) hak-hak apa saja patut diperjuangkan jika terjadi pelepasan tanah atau pencabutan tanah untuk pembanguna bandara; (b) apakah masyarakat dapat menggugatnya proses ganti rugi sepihak ke pengadilan atau cukup diselesaikan secara nonlitigasi (mediasi atau rekonsiliasi); (c) apa makna "fungsi sosial tanah" dan "kepentingan umum" dalam pengadaan tanah bagi pembangunan bandara sesuai UUPA dan UU No.2/2012. Masyarakat terdampak juga tidak tahu mekanisme pengaduan dan penyelesaian sejumlah persoalan hukum yang timbul. Untuk itu, digunakan metode kegiataan berupa (a) penyuluhan hukum dan HAM; (b) pelatihan nonlitigasi-penyelesaian sengketa di luar pengadilan/ADR dan litigasi/jalur pengadilan; (d) pembuatan buku saku/guideline penyelesaian konflik tanah; dan (e)public hearing/dengar pendapat dengan DPRD Kulonprogo dan pihak eksekutif. Dengan suasanan kegiatan yang dikemas sedemikian nonformal, dialogis, dan interaktif, diharapkan tingkat partisipasi warga di kedua Desa terdampak menjadi signifikan. Warga yang menjadi kelompk sasaran penerima manfaat diharapkan juga terlibat dalam memberikan feedback atau masukan terkait monitoringeveluasi dan keberlanjutan dari program ini di masa mendatang.
\end{abstract}

Keywords: Advokasi Hukum, Warga Terdampak, Konflik Tanah, Bandara NYIA..

\section{Metode Pelaksanaan}

Dalam rangka Pengabdian masyarakat ini dengan pendekatan pergi ke tempat yang dituju, menemui Kepala Desa Palian dan mengenal Desa Palian. Karena masa Covid-19, pendekatan lebih banyak kepada kepala desa. Informasi yang kami dapatkan sangat menggembirakan karena banyak hal dapat diselesaikan secara adil dan benar. Memang dari luar tampaknya seram dan menakutkan, kenyataannya tidaklah demikian. Mereka mengharapkan pendampingan itu, khususnya sekarang bagi warga yang masih ada dan terkena dampak pembangunan bandara. Mereka yang terkena dampak secara langsung sudah pindah ke tempat lain dengan mendapat ganti rugi yang adil dan memenuhi kebutuhan yang diharapkan. 


\section{Perlunya Advokasi demi Keadilan}

Warga terdampak pembangunan Bandara NYIA-Kulonprogo, terdiri atas lima desa, yakni Desa Glagah, Desa Kebonrejo, Desa Palihan, Desa Sindutan, dan Desa Jangkaran. Wilayah pembangunan Bandara NYIA-Kulonprogo meliputi 19 dusun, 2.700 kepala keluarga, dan 4.400 bidang tanah. Warga terdampak NYIA mulai mengetahui kabar tentang pembangunan Bandara NYIA sejak tahun 2011. Sesuai statistik BPS Kulonprogo dan sosialisasi yang dilakukan oleh Pemerintah Daerah, PT Angkasa Pura I, dan Badan Pertanahan Nasional (BPN) Kabupaten Kulon Progo pada 2014, wilayah yang terdampak bandara yakni seluas 673 hektare.

Pembebasan lahan untuk kepentingan pembangunan Bandara NYIA melibatkan sedikitnya 2.700 kepala keluarga yang terdampak dalam pembebasan lahan. Pembebasan lahan untuk lokasi bandara ini mempergunakan sistem konsinyasi. Pemilik tanah akan diberikan ganti rugi dengan cara melalui pengadilan pada proses pengadaan lahan untuk proyek yang didukung pemerintah. Proses pembebasan lahan ini ditentang oleh warga sekitar karena dianggap proses konsinyasi tidak berdasar dengan adanya penolakan untuk proyek tersebut sejak awal.

Penolakan terhadap pembangunan NYIA sudah dimulai sejak terbentuknya Wahana Tri Tunggal (WTT) pada 9 Desember 2012. Mayoritas anggota kelompok organisasi WTT adalah gabungan lintas para petani pemilik lahan, para petani penggarap, dan buruh-buruh tani yang terancam kepemilikan hak atas tanah mereka. Warga lantang menyuarakan penolakan di Desa Palihan. Alasan warga menolak pembangunan Bandara NYIA karena hilangnya ratusan hektare lahan produktif pertanian dan perkebunan yang selama ini telah menjadi sumber utama penghidupan mayoritas warga terdampak.

Pembangunan bandara ini masih menyisakan konflik hukum atau sengketa agraria bagi warga terdampak terutama di Desa Palihan yang sebagai desa mitra dalam program ini. Alhamdullilah, sengketa dapat diselesaikan secara adil dan benar. Desa ini dipilih sebagai kelompok sasaran penerima manfaat dengan banyak pertimbangan.

Ketika pembangunan bandara akan dilaksanakan, sebagain warga di Desa Palihan memang telah diajak bicara dan urun rembuk. Namun, pembicaraan tersebut mengalami kebuntuan karena (a) pemerintah yang selalu mengacu kepada UU No.2/2012 sehingga dianggap kurang memberikan ruang dialog atau musyawarah bagi masyarakat terdampak, terutama terkait nilai ganti rugi atas tanah, (b) pemerintah berisikeras untuk tetap membangun bandara dengan ganti rugi yang besarannya telah ditetapkan sepihak dalam anggaran proyek. (c) Warga di Desa Palihan juga menginginkan ganti rugi tidak hanya secara materiil, yakni bangunan dan tanah, tetapi juga ganti rugi atas tanaman pertanian/perkebunan, serta kompensasi berupa pengakuan atas sejumlah hak-hak lainnya agar mereka bisa hidup secara layak.

Proses ganti rugi berupa pencabutan hak atas tanah yang dijadikan sebagai objek pembangunan oleh pemerintah juga mengabaikan prinsip atau asas dalam pengadaan tanah untuk kepentingan umum, terutama asas kemanusiaan ${ }^{10}$ dan keadilan. Sebagian besar warga terdampak di Desa Palihan, Kecamatan Temon dipaksa harus menerima dengan tanpa syarat besaran ganti kerugian yang telah ditetapkan melalui panitia pengadaan yang dibentuk pemerintah tanpa perwakilan warga terdampak.

Paguyuban Warga Penolak Penggusuran Kulon Progo (PWPP-KP) juga menyatakan sikap tegas menolak kehadiran pembangunan Bandara NYIA tanpa syarat 
sehingga nilai ganti rugi dengan skema konsinyasi tidak berdasar. ${ }^{12}$ Tanah yang digunakan untuk pembangunan bandara merupakan lahan pertanian produktif yang menghasilkan buah dan sayur yang dapat menyuplai kebutuhan buah dan sayur di DIY. ${ }^{13}$ Bahkan, pada 28 November 2017, Ketua Ombudsman RI Perwakilan DIY, Budi Masturi, pernah meminta penundaan pengosongan lahan warga karena sedang melakukan investigasi terkait kemungkinan adanya mal-administrasi dalam proses tersebut.

Meski mendapat penolakan warga lewat organisasi seperti PWPP-KP, WTT, dan sejumlah relawan, PT Angkasa Pura I (Persero) tetap melanjutkan pembangunan Bandara NYIA-Kulonprogo hingga pada akhirnya dioperasikan perdana pada April 2018 silam walaupun masih bermasalah. Total tanah seluas 587,30 hektare dan digunakan sebagai lokasi bandara sebanyak 3.492 hektare. Hingga sekarang, sebagian besar biaya ganti rugi yang berjumlah milyaran rupiah masih mengendap di Pengadilan Negeri Wates-Kulonprog karena warga tetap pada pendiriannya, yakni menolak tanah yang menjadi hak miliknya diserahkan untuk pembangunan bandara. Masyarakat warga terdampak pembangunan Bandara NYIA selama ini tidak mempunyai pengatahuan hukum akan kepemilikan atas tanah-tanah serta cara proses pencabutan atau pelepasan hak atas tanah. Mereka juga tidak tahu mekanisme pengaduan dan penyelasaian sejumlah persoalan hukum yang timbul. Di sisi lain, Pemerintah Daerah tidak memerhatikan secara serius keberadaan masyarakat adat Ternate. Perlakuan diskriminatif masih banyak dijumpai dalam hal akses terhadap pemenuhan kebutuhan dasar di bidang sosial, pendidikan, kesehatan, dan pelayanan publik lainnya.

Serentak dengan itu, tatanan budaya yang masih dipegang kuat masyarakat, terutama hubungan patron-klien antara Keraton Yogyakarta dan masyarakat terdampak yang kebanyakan kurang pengetahuan, tidak memungkinkan masyarakat warga terdampak pembangunan terkuatkan untuk menuntut dan memperjuangkan hak-haknya. Dengan atas nama superioritas Keraton dan ketundukan yang berlebihan pada aturanaturan hukum tertulis, institusi-institusi negara kemudian dengan mudah manipulasi kesadaran publik untuk kepentingan tertentu dengan mengabaikan kepentingan umum. Masyarakat terdampak pembangunan Bandara NYIA Kulonprogo, pada dasarnya, memiliki kesadaran terhadap hak-haknya. Mereka juga menginginkan hak-hak mereka terpenuhi, tetapi tidak memiliki kapasitas, posisi tawar, dan keberanian yang cukup untuk menuntut dan memperjuangkan keadilan atas hak-haknya secara baik lewat jalur hukum dan pengambil kebijakan. Pemerintah mendengarkan serta merembuknya dengan adil dan benar.

Masyarakat yang kena dampak pembangunan Bandara ini sudah berpindah ke tempat lain. Pada saat proposal ini dibuat, justru mereka itulah yang harus kami dampingi agar hak-hak mereka itu dapat diberikan sebagaimana mestinya. Dari pantauan kami, hak-hak mereka telah diberikan dengan baik dan mereka telah berpindah semuanya. Memang masih ada dua lokal tanah dari dua keluarga yang belum beres, tetapi hal itu justru karena surat tanah yang tidak ada. Sekarang kasus tersebut sedang dalam pemyelesaian secara baik. Mereka pun akan mendapat hak-haknya sebagaimana mestinya.

\section{Kesimpulan}

Advokasi pendampingan masyarakat memang sangat penting agar masyarakat yang terkena dampak itu dapat menerima hak-haknya secara penuh. Sebagaiman yang 
ada sekrang ini, masyarakat menerima hak-hak mereka sepenuhnya. Memang masih ada satu bidang yang belum selesai penangannya karena yang bersangkutan tidak ada di tempat sini, tetapi ada di Jakarta. Hal ini perlu diteruskan pada warga masyarakat yang tidak terkena imbas secara langsung tanahnya dipakai untuk pembanguan bandara ini. Akan tetapi, mereka sebagai penduduk di situ justru yang terkena imbas pembangunan bandara itu. Perlu membangun sikap dan menerima pembangunan itu sebagai suatu kemajuan daerahnya.

\section{Ucapan Terima Kasih}

Dari hati yang tulus, kami mengucapkan terima kasih kepada LP3M Universitas Muhammadiyah Yogyakarta, kepada Kepala Desa Palian, dan warga desa tersebut.

Semoga pertemuan kita dapat memberikan sumbangan yang berarti bagi para saudara di desa tersebut. Kami juga mengucapkan terima kasih kepada beberapa rekan yang membantu pengabdian ini.

\section{Daftar Pustaka}

Anang Zakaria, Para Srikandi Penjaga Bum". beritagar.id. Diakses tanggal tanggal 25 Agustus 2019.

Artikel, Progres Pembangunan Bandara New Yogyakarta Internasional Airpor". liputan6.com. Diakses tanggal 25 Agustus 2019.

Akhmad Sopanudin, Konflik Lahan Pertanian dalam Pemabangunan Bandara Internasional di Kulon Progo, skripsi, Universitas Negeri Yogyakarta, 2016.

Idhom, Addi M. Dalih Angkasa Pura I dan Risiko Awetnya Konflik Bandara Kulon Progo - Tirto.ID".tirto.id. Diakses tanggal tanggal 25 Agustus 2019.

Artikel, Warga Kulon Progo Tolak Pembangunan Bandara".SINDOnews.com. Diakses tanggal 25 Agustus 2019.

Ahmad Naufal Azizi, Gerakan Organisasi Wahana Tri Tunggal Melawan Pembangunan Bandara di Kabupaten Kulon Progo, Daerah Istimewa Yogyakarta: Jalan Menemukan Kembali Hak Atas Kota. www//htpp.academia.edu. Diakses tanggal tanggal 25 Agustus 2019. 